This is the version of the chapter published in Melville, Charles, (ed.), Safavid Persia in the Age of Empires, ed. Charles Melville. London: IB Tauris, pp. 331-355. (The Idea of Iran) https://doi.org/10.5040/9780755633814.ch-014

Accepted version downloaded from SOAS Research Online: http://eprints.soas.ac.uk/34854

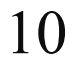

\title{
Shi'i Rulers, Safavid Alliance and the Religio-Political Landscape of the Deccan
}

\author{
Roy S. Fischel \\ (SOAS University of London)
}

I n 1631, the political order in the Deccan Plateau of South India was on the cusp of significant change as the Mughal Emperor Shah Jahan (r. 1628-58) embarked on a major campaign into the region. Understanding the graveness of the situation, the sultan of Golkonda, 'Abdollah Qotb Shah (r. 1627-72) delivered the following speech in his court in Hyderabad. His court historian, Nezam al-Din Ahmad Shirazi, recorded his words:

Our laudable ancestor, king and conqueror of the Kingdoms of Hendustan, Lord of the Happy Conjunction (saheb-qeran) ... with the assistance of the prophet's pure soul and of the commander of the believers 'Ali (Heydar), and with the help of the sacred spirits of the Twelve imams ... struck the heads and necks of the leaders of the vile infidels and lowborn Hindus in this country with his strength and power of bravery and with his sword that is like Zu'l-feqar ... [This way,] he conquered his kingdom. He spread the customs of the nation of Mohammad and the creed of 'Ali ...'

In this critical moment, the sultan chose to declare the raison d'etre of the sultanate in terms of the spread of Islam, clearly in its Shi' $i$ form, expressed in the invocation of 'Ali, his sword Zu'l-feqar and the Twelve imams.

Such rhetoric was not uncommon in the courts of the Deccan, and may have been used for domestic consumption. After all, when the situation seemed dire, members of the court, in particular Persianate nobles who had no special attachment to the sultanate, had the option to leave the Qotb Shahi court and join the Mughals, as several courtiers did; some two decades later, Mohammad Sa'id Ardestani, better known as Mir Jomla, famously took this very path. ${ }^{2}$ Therefore, a reminder of why the sultan deserved their support was essential. This idiom, however, was not limited to internal affairs. Similar language had been employed extensively in diplomatic correspondence among the Deccan Sultanates, and between them and the Safavids. In the latter case, another element was introduced 
to the mix: not only general use of Shi' $i$ tropes, but also more explicit expressions of Safavid allegiance.

Take, for example, an undated letter sent from Ebrahim Qotb Shah of Golkonda (r. 1550-80) to the Safavid Shah Tahmasp (r. 1524-76). Opening with a long list of Tahmasp's exalted titles, the letter states that:

[Qotb Shah] raised the banners of victory with divine help and the good fortunes of royal benevolence. He made the rows of the enemies, who were collected in the knot of the Pleiades ('aqd-e sorayya), disperse in the manner of Ursa's tail. ${ }^{3}$ Now he is in a position to fulfil the obligations of governance and to renew old bonds. It is evident that no one before us has raised the banner of propagating the imami creed in these lands! No one before us has spread the sublime Twelver khotba! Day by day, extreme effort has been made to strengthen the foundations of this great creed (mellat) and the rules of this superior Shari'a. ${ }^{4}$

Correspondence of this kind marks unambiguous links between the sultans of Golkonda and the Safavids, the core of which relies on shared Shi'i leanings.

Similar trends can be noted in the case of the neighbouring sultanate of Ahmadnagar. In 951/1544, Borhan Nezam Shah (r. 1510-53) sent Khurshah b. Qobad al-Huseyni as ambassador to the Safavid court. Having delivered presents (pishkesh) from India, Khurshah was granted audience with the shah. In his report, the ambassador stated that the shah:

inquired on the events in India and the circumstances of its rulers. He applauded the Refuge of the World (Borhan Nezam Shah) citing his own name following His Majesty's (Shah Tahmasp). The shah demonstrated endless kindness towards Shah Taher, who was the cause of the Shi' $i$ following (tashayyo ) of the Nezam Shah and the reason for the friendship and conciliation of the two sides. ${ }^{5}$

Similarly to Golkonda, in Ahmadnagar, too, the link with the Safavids was stated explicitly as relying on the shared creed. Special attention was given to the circumstances of the conversion of Borhan Nezam Shah. According to the chronicler Mohammad Qasem Astarabadi (better known by his pen name Fereshta), the sultan adopted Shi'ism after Shah Taher Hoseyni, the sultan's close adviser and confidant, managed to cure his son, Prince 'Abd al-Qader, when all others had failed. ${ }^{6}$ This version presents a major oddity. Shah Taher was most likely an Esma'ili; however, Borhan converted to Twelver Shi 'ism. ${ }^{7}$ This choice of creed may be an indication that the conversion, at least conceptually, had something to do with the Safavids.

Both Iranian and Deccani sources, then, indicate that the sultanates in the Deccan adopted Twelver Shi'ism as their official creed. The Deccan Sultanates are described as Shi'i states at the margins of the Safavid sphere of influence. Modern historiography has followed suit, at times uncritically. Edmund Herzig 
and Willem Floor pose the question, 'how important was the religious factor in the Safavid alliance with the Shi'i states of the Deccan?', thereby stating the creed of the sultanates as a matter of fact, without considering what this may entail. ${ }^{8}$ Moojan Momen proposes to fold the sultanates of Ahmadnagar, Bijapur and Golkonda into the Shi ${ }^{\circ} \mathrm{i}$ world by providing only skeletal details: conversion, migration of Shi'i ulema and Safavid links. ${ }^{9}$ Juan Cole argues that the Deccani courts modelled themselves after the Safavids in a linear story that begins with the proclamation of Shi ism as the state religion and ends with the Mughal conquest. The less straightforward case of Bijapur is depicted similarly, by saying that 'Shi' ism remained influential at this court, with a one or two-decade interlude, until late in the sixteenth century'. Cole thereby ignores the long interval between the end of the sixteenth century and the Mughal conquest in 1686. ${ }^{10}$ A similar approach is adopted by Roger Savory. Challenging E.G. Browne's claim that the Safavid period did not produce any great poets, he asks 'how was it that many Safavid poets flourished in the three Shi' $i$ courts in India: Ahmadnagar, Golconda and Bijapur?'. ${ }^{11}$

Modern historiography of India presents a similar approach. The prominent historian H.K. Sherwani argues that the relations between the Qotb Shahi sultans of Golkonda and the Safavids strengthened as Shi' ism became prevalent under the Safavids. He attributes the significance of the Safavids in the sultanate purely to religious issues. ${ }^{12}$ M.A. Nayeem offers a similar narrative regarding Bijapur, pointing to the temporal proximity in the introduction of that creed in both sultanates. He further suggests that 'the Perso-Bijapur collaboration in political and religious affairs had its repercussions not only on cultural and intellectual activities of the "Adel Shahi Sultans, but its impact penetrated deep into various aspects of life and society in Bijapur'. ${ }^{13}$ In his study of Shi' $\mathrm{i}$ Islam in India, Justin Jones mentions the 'Shi'a-informed dynasties in the Deccani South', where many 'established Shi'a cultural forms', ${ }^{14}$ without discussing their extent or impact.

The historiography that positions the Deccan Sultanates in ideological and diplomatic proximity to the Safavids is only to be expected. The sultanates emerged almost in parallel to the Safavids, whose historiography was marked by strong association with that creed. The Persian-speaking elite communities of the Deccan were influential in shaping political life there while maintaining intimate links to their ancestral lands. Accordingly, Persian sources of the Deccan, which were composed by members of the same community, promoted this vision as part of their appeal both to the Safavid rulers and to the wider Persianate world. As a result, the Deccan Sultanates, based on the proclamations found in their official chroniclers, were understood not only as Shi'i states, but in the Safavid form; the Safavids were assumed to be the gold standard against which the meaning of Shi' $i$ following was weighed.

However, the political, social and cultural circumstances in the Deccan varied significantly from those in Iran. Can we assume that the Safavid model was transferred to the Deccan in full? In this chapter I seek to question this 
assumption. Focusing on the sultanate of Bijapur under the rule of the Shi' $\mathrm{i}$ 'Ali I (r. 1558-80) and the Sunni Ebrahim II (r. 1580-1627), I argue that the meaning of Shi' $i$ state in the Deccan was significantly different from that in Iran. Showing more continuity than change between the two sultans, I suggest that many of the assumptions around their reigns were based on the importation of tropes that developed outside the subcontinent and could not be easily applied there. Instead, a careful inquiry into local circumstances demonstrates that the term 'Shi' $i$ ' in this context reflects a superficial label that has been neither all-encompassing nor total, as it was in Safavid Iran.

\section{Historiography of Binaries: Two Frameworks}

The identification of the Deccan Sultanates as Shi'i states is closely associated with historiographical trends constructed around questions of empire and early modernity. A growing body of literature produces a comparative framework for the analysis of the Ottoman, Safavid and Mughal Empires. The three were treated as interlinked entities, sharing similar beliefs, connected to the Turko-Mongol past and reliance on Perso-Islamic traditions. ${ }^{15}$ This process involved the crystallization and emergence of new religious orthodoxies, accompanied by the creation of legalistic discourses, all aimed at supporting the universalist claims of the rulers. ${ }^{16}$ This process is particularly evident in the Safavid and Ottoman cases.

The Safavids began officially to proclaim their following of the Shi'i creed with the establishment of their political rule in 1501 . Their notion of Shi'ism, however, continued to evolve with the changing political and ideological circumstances in the state. At first based heavily on ideas of messianism and extremism under the charismatic leadership of Shah Esma'il I (r. 1501-24), from the early 1530s the dynasty began to develop the more formal and doctrinal approaches of Twelver Shi'ism. This version of Shi'ism leaned increasingly heavily on the work of religious scholars, in part rejecting concepts of mysticism. ${ }^{17}$ Various Sufi orders began to be suppressed, first those solely identified as Sunnis, such as the Naqshbandis, later even the Ne'matollahis, who, from the beginning of Safavid rule, had allied themselves with the new dynasty. ${ }^{18}$ By the time of Shah 'Abbas I (r. 1587-1629), Twelver Shi'ism in its clerical, Shari'a-bound form was established at the heart of the empire as part of the effort to construct an integrated state system. ${ }^{19}$

Sunni orthodoxy became well established at the centre of the Ottoman Empire. From the late fifteenth and into the sixteenth century, learned classes were politicized and integrated into the imperial mechanism, producing an image of a state based on the Shari'a and justice. The intensified imperial order was supported by an evolving administrative and legalistic discourse and a bureaucratic apparatus, all with the aim of realizing the sultans' universalist claims. ${ }^{20}$ Central to this project, suggests Hüseyin Y1lmaz, was the concept of the caliphate, now reworked to allow its convergence with messianic ideas. This 
new form enabled the sultans to promote their sovereignty against similar claims of rival dynasties, Muslim and European alike, as well as within their own realm. ${ }^{21}$ Signs of heterodoxy were repressed throughout by the direct intervention of the central administration, while establishing approved elements (such as certain Sufi orders) in lieu of those considered too far from orthodoxy. These steps enhanced the crystallization of orthodoxy and the emergence of dichotomies between orthodox/heterodox, Sunni/Shi' ${ }^{2}{ }^{22}$

The result of the respective realignments of both dynasties was an intensified language of religious conflict. States and groups were labelled as either Sunni or Shi' $i$, promoting a growing distinction - and hostility - between the two creeds. ${ }^{23}$ The early modern period as a whole was perceived as an environment in which conflict between those two increasingly crystallized creeds was rife. These new binaries not only affected society within states but also served to define the relationship between dynasties. Beyond the direct Safavid-Ottoman conflict, works analysing Mughal-Ottoman and Mughal-Safavid relations referred to religion as a major issue. Religious sensitivities were evoked in the neverrealized possibility of an all-Sunni alliance, comprising the Ottomans, Ozbeks and Mughals, against the Shi'i Safavids. The same sensitivities were used to explain the tensions between the Ottomans and the Mughals regarding acceptance of the Ottoman claims to caliphate. ${ }^{24}$ In this historiographical environment, it was clear that the Deccan Sultanates ought to have been categorized as belonging to either side of the conflict.

The growing distinction between political Shi'a and Sunna, however, is not the only paradigm within which the Deccan Sultanates were examined. Upon arriving in the subcontinent, the binary scheme encountered the local circumstances, which were radically different from those in west Asia. At the heart of the local system stood a different set of binaries. To understand the local setting, let us diverge momentarily to consider the development of Muslim society in the Deccan.

Muslim rule in the region began during the reign of Mohammad $b$. Toghloq (r. 1325-51), sultan of Delhi. Under his rule, Muslim governors from north India were posted in towns in the Deccan, whereas other Muslims settled as rural landholders. In parallel, the position of certain pre-existing Hindu elites as landed gentry was confirmed and they were introduced into the service of the sultanate as assignment holders. ${ }^{25}$ Furthermore, in 1327, the sultan pronounced Dowlatabad in the northern Deccan his secondary capital, forcing nobles and civilians from the north to settle there. Others were lured by money or land grants. The short-lived project incentivized many to relocate to the Deccan, including Sufis, ulema and other members of the Muslim intellectual and political elites. ${ }^{26}$ These Muslims, who became the kernel of the Deccani Muslim society, gradually developed their own language, Dakhani, an amalgamation of north Indian languages but influenced by local vernaculars. ${ }^{27}$ 
In 1347, Delhi's rule collapsed and was succeeded by the locally grown Bahmani dynasty. The sultanate reflects a large degree of continuation of both Toghloq and local pre-Delhi titles and institutions, and both localized Muslims and Hindus played a significant part in various military and administrative roles. $^{28}$ Of particular importance were Sufis, welcomed in the region by the Bahmanis as part of their effort to construct their legitimacy as a rebel dynasty in an overwhelmingly Hindu environment. Two north Indian orders, the Cheshtiya and the Joneydiya, and one Iranian order, the Qaderiya, took root in the region. ${ }^{29}$ Notable among these was the Cheshti Sheykh Mohammad Hoseyni, better known as Khvaja Banda Navaz Gesu Daraz (d. 1422), who settled in the Bahmani capital, Gulbarga. Gesu Daraz established a new spiritual line within the Cheshti tradition. At the same time, he created a political centre opposing that of the sultan. ${ }^{30}$ The emergence of strong local Muslim elites, with their own linguistic identity, links to the place, association with certain Sufi orders and connections to Hindu elites, alerted the sultans. Consequently, Ahmad I (r. 142236) decided to engineer a new elite group from the new capital city he established in Bidar. He invited Iranians to settle, and increasingly relied on their services to run the sultanate. Self-styled 'Foreigners' (ghariban), these Persian-speaking elites became central in politics, administration and scholarship as well as international trade. ${ }^{31}$ The sultan further invited Ne'matollahi Sufis to settle in Bidar. Of this family, Shah Khalilollah gained great importance in the capital. His hospice linked together Foreigners, Sufis and the royal family, but did not extend far beyond these circles. ${ }^{32}$

The shift of power created tensions between Deccanis and Foreigners. These tensions became the hallmark of Deccani politics, even if modern historiography tends to exaggerate their extent; after all, the Bahmani sultanate remained relatively stable for well over a century. ${ }^{33}$ Nevertheless, a crisis of leadership in Bidar from the 1480s brought heightened tensions and the rapid collapse of Bahmani authority. By the turn of the sixteenth century, five de facto independent dynasties had emerged. Most important were the Nezam Shahs of Ahmadnagar, 'Adel Shahs of Bijapur and Qotb Shahs of Golkonda. ${ }^{34}$ The question of their sovereignty remains contested, however; we will return to this point later. With this newly acquired status, the sultanates, collectively known as the Deccan Sultanates, acknowledged each other's independence. None made any sweeping claims for sovereignty over the entirety of the former Bahmani domains. ${ }^{35}$

Within this system, the Deccani-Foreigner issue remained a significant framework in the history of the sultanates. Based on the development of the two groups, they were often perceived as total and all-encompassing opposites. Their contradictory characterization comprised several elements: the Deccanis were identified with the Dakhani language. Associated with the locality, they were considered to be susceptible to Indic culture and to cooperation with nonMuslims. D.C. Verma suggests, quite dramatically, that the Deccanis were primarily the descendants of local converts who were 'half Hindus in feelings, 
thought, speech, customs and dress' and 'had retained their way of life and outlook' ${ }^{36}$ The other group, namely the Foreigners, were linked to transregional networks. They were mostly Persian speakers, thus related to Persianate culture and to the wider Muslim world. Therefore, they were perceived as less sympathetic to Indic culture. This is reflected in the literary production of the two groups: the Foreigners wrote in Persian, the Deccanis solely in Dakhani. ${ }^{37}$

This clearly marked cultural distinction has naturally attracted scholarly attention. M.A. Nayeem suggests that the difference between Deccanis and Foreigners was racial; he even employs cranial morphology to make his point. ${ }^{38}$ A less objectionable approach emphasized the relations with the locality. Trying to create a more harmonious understanding of the sultanates, and in line with the twentieth-century project of state-building in India, H.K. Sherwani coined the terms 'New-comers' (Foreigners) and 'Old-comers' (Deccanis). With these terms, he acknowledged the genealogy of the elite clusters as fundamental in shaping the complex relationship between them. ${ }^{39}$ S.R. Sharma emphasizes the unique nature of Deccani culture, stating that, due to the isolation of the community, its culture developed differently from those of the foreign Muslims. ${ }^{40}$ Among these suggestions, a common attempt to explain the conflict was in terms of creed. Considering the origin of each group and the broader historical development in the early modern period, Foreigners now became associated with the Shi' $i$ creed, and the Deccanis with Sunni Islam. Not only the elites but even the rulers themselves were included in this division, associating each sultan's creed with a preferential treatment of their co-religionists-cum-elite group, while subduing rivals. ${ }^{41}$

The collision of the two binaries, then, creates a clear distinction between two groupings. On the one hand stood the Foreigners, who were associated with the cosmopolitan Persianate world and transregional networks; as such, they were viewed as indifferent, if not hostile, to the Deccani environment and Indic culture, and therefore not likely to cooperate with Hindu elites. Identified as Shi' $i$, and following the developments in the Safavid realm, they were also increasingly depicted as hostile towards Sufism, with the possible exception of the $\mathrm{Ne}^{\text {'matollahi order. }}{ }^{42}$ The Deccanis were perceived as the mirror image of the Foreigners. Closely linked with the Deccan rather than anywhere else in the subcontinent or the outside world, they were understood as operating along local lines. Associated with the Dakhani language, they were only happy to cooperate with Hindu elites and showed sympathies to both Indic culture and the vernaculars. As Sunnis they were also closely associated with Sufism. This scheme is presented in Table 1.

Table 1: Attributed differences of Foreigners and Deccanis

\begin{tabular}{|l|l|l|}
\hline & Foreigners & Deccanis \\
\hline Orientation & Cosmopolitan & Local \\
\hline Language & Persian & Dakhani; vernaculars \\
\hline
\end{tabular}




\begin{tabular}{|l|l|l|}
\hline Creed & Shi ${ }^{i}$ & Sunni \\
\hline Culture & Perso-Islamic & Islamic/Indic \\
\hline Sufism & Hostile & Sympathetic \\
\hline
\end{tabular}

\section{Bijapur and the Dissolution of Binaries}

To what extent can we assume that this binary model offers a viable representation of political life in the Deccan? The sultanate of Bijapur provides an interesting case study to examine the model's validity. Unlike its neighbours in Golkonda, whose rulers were Shi' $i$ from the establishment of the dynasty, and in Ahmadnagar, where the sultans adopted that creed early on, the 'Adel Shahi rulers of Bijapur reflect a more changeable story. The sultanate emerged around 1490 under the Shi'i Yusof 'Adel Khan (d. 1510), a Foreigner in Bahmani service. Throughout the sixteenth century, the rulers' creed changed constantly: Yusof's successor Esma'il (r. 1510-34) remained Shi'i, Ebrahim I (r. 1535-58) was Sunni, 'Ali I (1558-80) Shi'i and Ebrahim II (1580-1627) again Sunni.

As Bijapur inherited many of its elite structures from the Bahmanis, including the Foreigner-Deccani divide, these switches led scholars to assume that such changes in the rulers' creed meant that the sultanate as a whole changed its course radically. A notable example of this approach is provided by Richard Eaton and Phillip Wagoner. They describe the Shi'i Esma'il as 'devoted to foreign - that is, Persian - culture', therefore he 'seldom spoke the Dakhni language, and also vowed that he would never enlist Deccanis and Habshis (Ethiopian military slaves) in his service'. He even 'ordered his entire army to wear scarlet caps with twelve points' in the Safavid manner. In contrast, Esma'il's Sunni son Ebrahim I 'fervently favored Deccanis', preferred vernaculars over Persian and prohibited the Safavid cap. Moreover, he changed the language of revenue accounts and judicial records from Persian to the local vernaculars, Marathi and Kannada, and appointed Brahmins in the administrate system. Ebrahim later integrated elements from the local, pre-Islamic Western Chalukya Empire in his public architecture. $^{43}$

This kind of narrative is limited in several points. It is not clear how sweeping and clear-cut those changes were. No evidence for literary patronage of either Marathi or Kannada by Bijapur's elites is noted (but this may be the result of limited scholarly attention). Furthermore, the boundaries between language at the time are questionable. Sumit Guha suggests that early state documents in Marathi, while written in Modi script, were comprised mostly of Persian vocabulary and even grammar, with only occasional terms and verbs taken from Marathi. $^{44}$

The problems run much deeper. The scheme of radical change itself reflects the persistence of the colonial-era perception of Great Men, in which the ruler alone sets the tone for his kingdom. This notion had been used already in the early nineteenth century by James Mill, to whom the declared religion of the ruler defined the entire era. ${ }^{45}$ That Eaton and Wagoner follow this idea is striking, 
considering that elsewhere they both rightfully reject the similarly clear-cut, generations-old and outdated division between Muslims and Hindus. ${ }^{46}$ Moreover, the scheme assumes extreme discontinuities in the history of Bijapur, in particular when compared with Ahmadnagar and Golkonda. This assumption is questionable if we consider the resilience and stability of the sultanate, which until the mid-seventeenth century retained its position as the strongest state in the Deccan. Furthermore, total changes imply monolithic views of each group. However, this might be a gross oversimplification: consider how diverse must be the opinions among the members of a group comprising local Muslims, Ethiopian military slaves, Marathas and Kannada-speaking Brahmins.

A careful examination of the two sultans that followed Ebrahim I demonstrate the problems in this model. Ebrahim I's son, 'Ali I, ascended the throne of Bijapur in 1558 at the age of 16, even though it is reported that his father was reluctant to promote him due to his Shi' ${ }^{i}$ inclinations. Nevertheless, the prince enjoyed the support of both the nobles and the larger population; upon Ebrahim's death, he was selected to succeed him. ${ }^{47}$ Under 'Ali's rule, state power expanded considerably, in particular following the defeat of the formidable neighbour to the south, Vijayanagara, in 1565. Extensive construction projects mark the turning of Bijapur into a major political centre. During these important developments, 'Ali's Shi' 1 inclination did not result in the anticipated exclusions. No change of administrative language is recorded, of the kind mentioned under Ebrahim I. Even though 'Ali is said to have favoured Foreigners, Hindus continued to serve in the royal armies. Some attained high rank, including various generals and the auditor-general (majmu'-e mamalek), Daso Pandit, whose family remained interlinked with the "Adel Shahs into the reign of Ibrahim II. ${ }^{48}$ An interesting reflection of 'Ali's association with Hindus can be found in an inscription on the newly built city wall, stating that the segment was built by one Pandit Nandji. Underneath the inscription, a ritualistic Chalukya-period gate is integrated into the wall, resonating with localized historical memory. ${ }^{49}$ Another inscription on the wall opens with the Shi' $i$ formula 'No hero like 'Ali! No sword like Zu'l-feqar!'. ${ }^{50}$ While this kind of statement is only to be anticipated under a Shi' $i$ ruler, it is surprising that the person associated with the use of this language was a Hindu named Jagdeva Rao.

Sufis, too, were not shunned. Rafi ‘ al-Din Shirazi reports that the sultan was fascinated by Muslim and Hindu ascetics, and constantly sought their company. ${ }^{51}$ This kind of Shi ${ }^{\circ} \mathrm{i}-\mathrm{Sufi}$ association was commonplace in the Deccan, and was not limited to the $\mathrm{Ne}^{\text {' } m a t o l l a h i s . ~ M o s t ~ v i s i b l e ~ a r e ~ f u n e r a r y ~ p r a c t i c e s ~ t h a t ~ b r o u g h t ~}$ sultans and saints into close spatial (and spiritual) proximity. The first two sultans of the "Adel Shahi dynasty, both Shi' $i$, were buried in a royal necropolis in Gogi, some $110 \mathrm{~km}$ east of Bijapur, near the resting place of the Sufi Sheykh Chanda Hoseyni (d. 1454) ${ }^{52}$ This reflects continuity with the Bahmani sultans, whose necropolis near Bidar was built in proximity to the tomb of the $\mathrm{Ne}$ 'matollahi Shah Khalilollah (d. 1455). ${ }^{53}$ 'Ali I broke this tradition, as his mausoleum moved 
away from Gogi to Bijapur. Yet, as Deborah Hutton suggests, his tomb reflects important aspects of continuity: 'Ali's modest mausoleum was modelled after Gogi's royal tombs and was built near, and in association with, the tombs of Qaderi Sufis' ${ }^{54}$ Correspondence between Bijapur and Golkonda during his reign evokes the name of the Cheshti saint Gesu Daraz. ${ }^{55}$ 'Ali's Sufi sympathies correspond with the wider Shi'ite-Sufi affinity in the Deccan. An early seventeenth-century painting, titled 'Dervish receiving a visitor', depicts Shi'i 'alams (metal banners, typically carried in the Shi'i procession on 'Ashura) resting on a Sufi shrine. ${ }^{56}$ In the unequivocally Shi'i Golkonda, too, Sufis were highly esteemed: they were second only to the sultans in the prominent place given to their tombs in the royal necropolis near Golkonda Fort, and their tombs shared similar architecture to those of the sultans. Marital connections cemented the links between Qotb Shahi sultans and prominent Sufis. ${ }^{57}$

'Ali's links with local elites were not solely utilitarian. A deeper engagement is expressed in a curious work, titled Nojum al-'olum. Composed in Persian before 1570 , probably by the sultan himself, the Nojum is an innovative composition which brings together esoteric knowledge from Indic, Hellenic, Central Asian, Persian and Islamic traditions, in writing and with hundreds of illustrations. The work elaborates on ideas of kingship, which included the Indic concept of the sultan as universal ruler (chakravartin), thus reflecting an exchange within the composite environment of the Deccan and with Indic concepts. ${ }^{58}$ Furthermore, Emma Flatt suggests that 'Ali promoted a territorial claim that connected him to particular places in the Deccan, even beyond his own realm. ${ }^{59}$ Similarly to the reign of Ebrahim I, 'Ali, too, made use of Chalukya symbols. Eaton and Wagoner demonstrate that, under 'Ali, a Chalukya-era temple in newly conquered Bankapur was converted into a mosque while maintaining its original form. This conversion serves as an example of the integration of local pasts into the expanding sultanate. ${ }^{60}$ Another sign of this engagement is in the major musical treatise Sangitaratnakara. Katherine Butler Schofield suggests that this work was translated from Sanskrit into Dakhani in Bijapur around $1570 .{ }^{61}$ Considering 'Ali's personal involvement, his engagement with the locality seems more than merely Realpolitik, but rather the reflection of a deeper affiliation with the local idiom, contrary to what might be expected from a Shi'i ruler.

The childless 'Ali I was succeeded in 1580 by his nephew Ebrahim II, who soon changed the sultanate's official creed to Sunnism. According to the standard historiography, this would therefore presuppose that he would prefer Deccanis over Foreigners, be disinterested in Persian and the Persianate world, demonstrate localization and heavily engage with Sufis. ${ }^{62}$ Much of this does indeed reflect Ebrahim's interests. Remembered for his contribution to the development of a unique, localized and hybrid courtly culture, his royal identity was constructed around the deliberately ambiguous concept of nowras. This term carries a double meaning: in Persian, nowras means 'newly arrived', reflecting 
the sultan's youth and innovation; in Sanskrit, nava rasa (written as nowras in nasta 'liq) or nine rasas (emotional essences) are associated with music and are experienced through the senses. ${ }^{63}$ Ebrahim composed Ketab-e nowras, a collection of songs in Dakhani, written to be sung to classical Indian music. Laden with Sanskrit terminology, this composition reflects aesthetics and themes related to Indic poetry. The verses famously invoke Sarasvati (goddess of knowledge and music), the Prophet Mohammad and the Cheshti Sufi Gesu Daraz. ${ }^{64}$ On the other side of this alleged zero-sum game, Ebrahim was also reported to have only rudimentary knowledge of Persian. Famously, the Mughal ambassador Asad Beg Qazvini, who visited Bijapur in 1603, reports that Ebrahim spoke only broken (shekasta) Persian. ${ }^{65}$

A careful examination of the evidence, however, suggests a much deeper engagement with elements which were considered to belong to the 'Foreign' side. Keelan Overton demonstrates the variety of Persianate intellectuals who settled in Bijapur during the reign of Ebrahim II, thanks to the 'welcoming climate for foreigners'. The Foreigners were central to the intellectual scene of the capital, linking it to the world of Persianate cosmopolitanism. ${ }^{66}$ These circles included the leading poets Nur al-Din Mohammad Zohuri and Malek Qommi, who migrated from Ahmadnagar, and Zohuri's son, Zahur, who composed the chronicle Mohammadnama for Ebrahim's successor, Mohammad. ${ }^{67}$ The Shi 'i intellectual Khvaja Sa'd al-Din 'Enayatollah Shirazi, along with the poets Molla Shakibi and 'Enayatollah Ardestani, arrived in Bijapur, entered royal service, and received land grants (soyurghal). Khvaja Sa'd al-Din became Ebrahim's close counsellor with a new title, Shah Nawaz Khan. ${ }^{68}$ Royal patronage was extended to the historians Rafi' al-Din Shirazi and Fereshta, who composed Persian chronicles for the sultan. The climate of openness towards the Islamicate, particularly Persianate, cosmopolitan world, is reflected in the contents of Ebrahim's library and its function as a nodal point for the circulation of manuscripts in Persian and Arabic. Overton suggests that the library contributed to the creation of Ebrahim's firm image as a Muslim sovereign. ${ }^{69}$

Fereshta's personal testimony is particularly revealing. In sections not included in the oft-used translation by John Briggs, the chronicler depicts a ruler who was deeply involved in Persianate culture and language. He reports that, at a time when he was facing financial difficulties, he attended a royal council (majles), where the sultan personally increased his rank (mansab) and land grant (eqta). The sultan then gave the chronicler a copy of Tarikh-e Rowzat al-safa' and ordered him to write an 'honest' account on his reign in that manner. ${ }^{70}$ Fereshta further suggests that the sultan recognized the need to learn Persian and made an effort to master the language. Ebrahim started by reading one or two lines of a report, gradually progressing to poetry and prose, until becoming well versed in the language..$^{71}$ Even if we choose not to accept Fereshta's favourable report unreservedly, it is clear that the official chronicler saw it as crucial to depict his patron as part of the cosmopolitan Persianate world. 
Other references link Ebrahim more directly to the Shi'i creed. In Golzar-e Ebrahim, Zohuri mentions the sultan's 'good fortune of submission to the illustrious Shari'a of Mostafa (i.e. Mohammad), and the felicity of raising the banner of friendship for Mortaza (i.e. 'Ali)', to which he adds that 'a proof of his pure nature [is] his love of the pure Imams'. ${ }^{72}$ A similar reference to 'Ali can be found on copper coins from his reign. ${ }^{73}$ An even more direct reference appears in yet another (not translated) section from Fereshta. The chronicler reports that in Moharram of 1004/September 1595, the sultan encamped to perform the Shi' $i$ rites of mourning. In the following year, the Shi'i scholar Mir Mohammad Saleh Hamadani arrived in India. Ebrahim organized a royal reception for him. On the tenth day of Moharram, the sultan performed the mourning rites, 'in accordance with the custom of previous years'. He then invited Mir Mohammad to join him in Bijapur's citadel. When the caravan approached, the sultan 'walked on foot a long way to receive him, and performed a prostration (sejda) of thanksgiving', showing particular reverence to the Shi' $i$ scholar. ${ }^{74}$

Ebrahim 'Adel Shah II, just like his uncle 'Ali I before him, did not conform to the restrictive model. 'Ali's Shi'i inclinations and Ebrahim's Sunnism did not determine their approach in many ways. On the contrary, instead of a narrative of abrupt changes, and notwithstanding the declaration of changing creeds, both sultans demonstrate a large degree of continuity in all aspects: from language and employment to royal imagery and architecture. ${ }^{75}$ Even in religious issues, much continuity can be observed: this included veneration of Sufis, and even in Shi'i rituals proper. It was not only Bijapur that defied the model; in Golkonda, too, the Shi' $i$ rulers created direct links to the pre-Muslim past by constantly referring to the heritage of the pre-Islamic Kakatiya dynasty, by providing patronage to literary works in Telugu as well as Dakhani, and by maintaining their links with Sufis. ${ }^{76}$ All this suggests that we should reject outright the rigid model of clear distinction between Sunni and Shi'i rulers and the implications thereof.

\section{Shi 'i States of the Deccan?}

The direction that the various sultans of the Deccan took in their policies with regard to the local scene, other creeds, the Hindu population and Sufis differentiated them from their contemporaries in Iran. Instead of sectarian schism, as reflected within the Safavid realm and in the relations with their neighbours, the sultans of the Deccan preferred inclusive policies. With continuous patronage of Sufis and Hindus, and without any sign of enforcing their creed over the Muslim population, which remained overwhelmingly Sunni, ${ }^{77}$ it appears that applying the Safavid standards to the Deccan contributes little to our understanding of the region. This inapplicability derives from the special circumstances which emerged in the early modern Deccan. Unlike the Ottomans and Safavids, the Deccan Sultanates lacked any unified political centre that could impose its ideas on the population. Moreover, facing competition from sister-sultanates and threats from powerful neighbours, first Gujarat and 
Vijayanagara and later the Mughals, the very survival of the sultanates depended on their ability to secure the cooperation of various elites. Those included Deccani Muslims, Ethiopian military slaves, Hindu military and administrative groups, and Persian-speaking Foreigners. The elites had other options, from noncooperation to joining the rivals, giving them leverage in their negotiations with the sultans. These circumstances encouraged the political culture of the region to take the opposite direction to that of the contemporary empires: instead of an increasingly authoritative centre with clear ideological preferences, the sultans encouraged the concurrence of multiple voices. ${ }^{78}$

This polyvocality may be the key to understanding the seeming contradiction between continuity and change. The changes in the political language of Bijapur, or the lack thereof, illustrate this point. Allegedly related to the opposite poles of Bijapur's courtly culture, in reality 'Ali I and Ebrahim II were not so different from one another. Both demonstrated keen interest in Indic culture and were involved in literary production in local traditions, either directly or by providing the conditions for them to flourish in their court. Both were associated with patronage of Persian culture and Shi $i$ learning and kept cordial relations with the Safavids while maintaining links to Sufi saints; both similarly challenged the neat division of the court into two contradictory and competing traditions.

To this we should add the official language used by the sultans towards the Safavids. As we have seen before, this language presents a direct expression of alliance towards the empire, not only politically but also ideologically. A curious example is a letter from Ebrahim II to Shah 'Abbas I, sent in early 1623:

The lands of the Deccan form as much a part of the Safavid Empire as the provinces of Iraq, Fars, Khorasan, and Azerbaijan. Accordingly, the names of the Safavid monarchs have been recited in the sermon and will continue to be recited in future. Our forefathers were appointed to rule over these territories and protect them by His Majesty's ancestors. So our function is to rule the countries on his Majesty's behalf and defend them against foreign aggression. ${ }^{79}$

The letter states that the Sunni sultan of Bijapur not only acknowledged the Safavid role in appointing the "Adel Shahi sultans (a doubtful statement, considering that the "Adel Shahi sultanate emerged before the Safavid Shah Esma'il I entered Tabriz in 1501), but that he was happy to commit to Safavid sovereignty, expressed by the khotba. The acceptance of Shi' $i$ khotba by a Sunni ruler made some uncomfortable. Riyazul Islam refers to the 'absence of any reference to the Shi' $i$ Imams which is such a prominent feature of letters sent from the Deccan courts in Iran' ${ }^{80}$ This tension further highlights a specific view of the meaning of the khotba as a sign of Deccani acceptance of Safavid sovereignty with all its symbols. ${ }^{81}$

The contradiction, however, reflects a particular understanding of both creed and khotba which, again, may not be applicable to the early modern Deccan. 
Elizabeth Lambourn argues that, in the early modern period, the idea of khotba was contested. Its concept changed over time and according to place, creating tensions between sovereigns, each with his own understanding of its meaning. ${ }^{82}$ Sebastian Prange suggests that, on the late-fourteenth-century Malabar Coast, the khotba was not as much a statement of political sovereignty as it was a means for distant communities to cement commercial links. ${ }^{83}$ More generally, Dariusz Kołodziejczyk comments that the question of sovereignty itself has never been straightforward, but reflects aspects of control and ideology: the position of a local ruler, his ability to assert imperial control or concepts of inside/outside. ${ }^{84}$

With these reservations in mind, I suggest that the Safavid khotba was, indeed, not necessarily a matter of sovereignty or religious incorporation. Rather, it was intended to link the sultanates to the Safavids as a measure of symbolic protection against the Mughals. In that sense, the Shi' $i$ references are not so much confessional as a declaration of political association in the polarized conditions of the early modern Muslim world. Reciting the Safavid khotba (or at least declaring a willingness to do so) and describing long-lasting bonds reflect Deccani lack of confidence in the face of the Mughal advance. This understanding of sovereign symbols as signifying a reaction to insecurities can also explain why Deccani minting appeared only in the 1580s. Pushkar Sohoni suggests that the late beginning of minting should be interpreted as a local response to the Mughal advance. ${ }^{85}$ The symbolic aspect of the khotba is made even clearer when we consider the distance of the Safavids from the Deccan, which meant that no actual help could have been sent. Taken together, the evidence supports the view that reciting the Safavid khotba in the Deccan represented an indicative means of demarcating territory in a highly contested environment, while rejecting Mughal designs. Moreover, acceptance of the khotba represents the choice of a distant symbol, which could not in reality curtail Deccani independence.

In this case, then, what is the meaning of seeing the Deccan Sultanates as Shi' $i$ states, if indeed such a state existed at all? It is true that many of the rulers saw themselves as followers of that creed; for the Nezam Shahs and Qotb Shahs it continued throughout the tenure of the sultanate, whereas for the 'Adel Shahs, only intermittently during the sixteenth century. Furthermore, correspondence between rulers of all three dynasties and the Safavids contained elements of acknowledging both Safavid sovereignty and a Shi'i following. However, we cannot take the Shi'ism of the sultanates beyond that. While using creed enables us to position the Deccan within the early modern Muslim world, it also produces certain misunderstandings regarding the meaning of this position.

Furthermore, we should ask whether the religious affiliation of the ruler was the sole determinant of the orientation of the state, and even of courtly culture. I propose that it was not. In the Deccan, the majority of Muslims remained Sunni, and no evidence suggests that there was any attempt to impose a new creed on them. Moreover, the Shi'i sensitivities of some rulers were operating in an 
environment that encouraged, even endorsed, multiplicity. Even though Shi' $\mathrm{i}$ allegiance was forcefully promoted in official writings, it did not prevent the ruler from pursuing other directions as well. This flexibility highlights the general continuities of courtly culture and its independence of Safavid or any other influence. More so, it emphasizes the flexibility of cultural and religious boundaries which continued in the Deccan into the seventeenth century. The idea that the Deccan Sultanates were solidly Shi' $i$ in the binary, Safavid-inspired way seems to be ill-suited for the Deccani environment. There is no doubt that the Safavid Empire, with its Shi'i sensitivities and Persianate culture, played a significant role in the shaping of the Muslim sultanates of central India. But the sultanates' response diverged from the ideas projected from Iran, as sultans fashioned their political and religious identities in a way that was uniquely Deccani. 


\section{Notes:}

1. Nezām al-Din Ahmad Shirāzi, Hadīqat al-salātin, pp. 128-29.

2. On his career, which spanned from Iran to Qotb Shahi service and then to the Mughals, see Jagadish Narayan Sarkar, The Life of Mir Jumla.

3. Banätu'n-na 'sh, a term referring to the row of three stars at the tail of both Ursa Major and Ursa Minor. I wish to thank Dr Moya Carey, Chester Beatty Library, Dublin for her assistance in translating this term.

4. Qāsem Tabasi, Enshā-ye Qāsem Tabasi, fols. 131v-132r.

5. Khurshāh b. Qobād al-Hoseyni, Tārikh-e Ilchi-ye Nezām-Shāh, pp. 153-54.

6. Mohammad Qāsem b. Hendu-Shāh Fereshta, Tārikh-e Fereshta, vol. II, pp. 218-25.

7. Farhad Daftary suggests that this is a sign that, even in Ahmadnagar, Shah Taher continued to practise taqiya (dissimulation), see Farhad Daftary, The Ismá ${ }^{`} i \bar{l} \bar{l} s$, pp. 453-54.

8. Edmund Herzig and Willem Floor, 'Introduction', p. 2.

9. Moojan Momen, An Introduction to Shi 'i Islam, p. 121.

10. Juan I.R. Cole, 'Iranian culture and South Asia', pp. 25-26.

11. Roger M. Savory, Iran under the Safavids, pp. 203-4.

12. H.K. Sherwani, History of the Qutb Shahi Dynasty, p. 432.

13. M.A. Nayeem, External Relations of the Bijapur Kingdom, p. 54.

14. Justin Jones, Shi 'a Islam in Colonial India, pp. 4-5.

15. See, for example, Cornell H. Fleischer, 'The lawgiver as messiah'; Stephen F. Dale, The Muslim Empires of the Ottomans, Safavids, and Mughals.

16. Giancarlo Casale, 'The Islamic empires of the early modern world', pp. 334-37.

17. Kathryn Babayan, Mystics, Monarchs, and Messiahs, pp. 141-60; Colin P. Mitchell, The Practice of Politics in Safavid Iran, pp. 68-87.

18. Said Amir Arjomand, The Shadow of God and the Hidden Imam, pp. 109-18; Momen, Shi 'i Islam, pp. 109-11, 213.

19. Rula Abisaab, Converting Persia, pp. 53-87.

20. Cornell H. Fleischer, Bureaucrat and Intellectual, pp. 253-72; Boğaç A. Ergene, 'On Ottoman justice'; Abdurrahman Atç1l, Scholars and Sultans; Heather L. Ferguson, The Proper Order of Things.

21. Hüseyin Y1lmaz, Caliphate Redefined.

22. Suraiya Faroqhi, 'Seyyid Gazi revisited', pp. 90-98; Markus Dressler, 'Inventing orthodoxy'.

23. Cemal Kafadar, Between Two Worlds, pp. 60-117.

24. This is, of course, not to say that Realpolitik has no role in shaping the relationship. See Martin M. Dickson, 'Sháh Tahmásb and the Uzbeks' and discussion on pp. 4246; Adel Allouche, The Origins and Development of the Ottoman-Safavid Conflict; Naimur Rahman Farooqi, Mughal-Ottoman Relations.

25. Richard M. Eaton and Phillip B. Wagoner, Power, Memory, Architecture, pp. 27-28; Richard M. Eaton, A Social History of the Deccan, pp. 24-26, 37-43; Simon Digby, 'Before Timur came'; Hiroshi Fukazawa, The Medieval Deccan, pp. 1-48; Sumit Guha, 'Serving the barbarian to preserve the dharma', pp. 505-10; Peter Jackson, The Delhi Sultanate, pp. 202-3, 210, 251.

26. Jackson, Delhi Sultanate, pp. 164-65, 207-13, 232, 258-63; Eaton, Social History, pp. 34-43; Mahdi Husain, Tughluq Dynasty, pp. 144-64.

27. David J. Matthews, 'Dakani Language and Literature'. 
28. H.K. Sherwani, The Bahmanis of the Deccan, pp. 53-120; V. Yashoda Devi, After the Kakatiyas, pp. 65-67; S.K. Sinha, Medieval History of the Deccan, p. 131.

29. Muhammad Suleman Siddiqi, The Bahmani Sufis, pp. 31-70, 95-116.

30. Eaton, Social History, pp. 47-58; Siddiqi, Bahmani Sufis, pp. 31-69, 119-49, 19798.

31. Sanjay Subrahmanyam, 'Iranians abroad'; idem, 'Of imarat and tijarat'; Sherwani, Bahmanis, pp. 120-50; G. Yazdani, Bidar, pp. 3-9; Muhammad Suleman Siddiqi, 'The ethnic change at Bidar and its influence', pp. 65-68.

32. Siddiqi, Bahmani Sufis, pp. 150-87; Siddiqi, 'Ethnic change'; Peyvand Firouzeh, 'Sacred kingship in the garden of poetry', p. 212.

33. Eaton, Social History, pp. 67-70.

34. The sultanates proclaimed their sovereignty, expressed by the introduction of the title shah, only with the death of the last Bahmani sultan, Kalimollah, in 1538. see H.K. Sherwani, 'The "independence" of Bahmani governors'.

35. Richard M. Eaton and Phillip B. Wagoner, 'Warfare on the Deccan Plateau'.

36. D.C. Verma, Social, Economic and Cultural History of Bijapur, pp. 21-24.

37. Virtually all known chroniclers who wrote in Persian were Foreigners, with a nesba such as Astarābādi (Fereshta), Shirāzi or Tabātabā'i. Similarly, Persian poets in the Deccan were Iranian migrants, including the celebrated Zohuri and Malek Qommi. See T.N. Devare, A Short History of Persian Literature, pp. 67, 94-98, 186-236, 32430; E.G. Browne, A Literary History of Persia, vol. IV, pp. 110, 253.

38. Nayeem, External Relations, pp. 52-53.

39. Sherwani, Bahmanis, pp. 131-34, 151-73.

40. S.R. Sharma, 'A note on the cultural background of political struggles in medieval Deccan', p. 174.

41. Verma, Social, Economic and Cultural History, pp. 14, 186; Nayeem, External Relations, pp. 55-60; Eaton and Wagoner, Power, Memory, Architecture, pp. 12629; Radhey Shyam, The Kingdom of Ahmadnagar, pp. 80-85. Cole, 'Iranian culture and South Asia', p. 25, suggests that the ritual cursing of Sunni sacred figures in Bijapur provoked riots. However, he does not provide any evidence, and I have not encountered cases of this kind.

42. Richard M. Eaton, The Sufis of Bijapur, pp. 70-75; Momen, Shi 'i Islam, pp. 109-11, 213.

43. Eaton and Wagoner, Power, Memory, Architecture, pp. 125-33.

44. Sumit Guha, 'Mārgī, Deśī, and Yāvanì̄, pp. 134-37.

45. James Mill, The History of British India.

46. See, for example, Eaton, Social History; Phillip B. Wagoner, 'Sultan among Hindu kings'.

47. Tārikh-e Fereshta, vol. II, pp. 64-65; P.M. Joshi, 'The 'Ādil Shāhis and the Baridis', vol. II, p. 325.

48. Rafi` al-Din Ebrāhim Shirāzi, Tadhkerat al-moluk, p. 189.

49. M. Nazim, Bijapur Inscriptions, no. 426, pp. 49-50; Eaton and Wagoner, Power, Memory, Architecture, pp. 137-38.

50. Nazim, Bijapur Inscriptions, no. 3312, p. 49. Eaton and Wagoner, Power, Memory, Architecture, p. 137, mention the name of the sovereign but, oddly, ignore the Shi' 1 slogan at the beginning of the inscription.

51. Shirāzi, Tadhkerat al-moluk, pp. 56-57. 
52. Deborah Hutton, Art of the Court of Bijapur, pp. 26-47.

53. Yazdani, Bidar, pp. 141-46; Siddiqi, Bahmani Sufis, pp. 78-83.

54. Hutton, Bijapur, pp. 42-51; G. Yazdani, 'Inscriptions of Shahpur, Gogi and SagarGulbarga District', pp. 5-9; George Michell and Mark Zebrowski, Architecture and Art of the Deccan Sultanates, p. 88.

55. Enshā-ye Qāsem Tabasi, fol. 131v.

56. Hutton, Bijapur, p. 177, n. 62.

57. Marika Sardar, 'Golconda through Time', pp. 105-9.

58. Emma J. Flatt, 'The authorship and significance of the Nujum al-ulum'; Hutton, Bijapur, pp. 50-69.

59. Flatt, 'Nujum al-ulum', pp. 225-29.

60. Eaton and Wagoner, Power, Memory, Architecture, pp. 134-46.

61. Katherine Butler Schofield, 'Music, art and power in 'Adil Shahi Bijapur'.

62. Eaton, Sufis of Bijapur, pp. 89-105; Eaton and Wagoner, Power, Memory, Architecture, pp. 149-51.

63. Zohuri, Nauras, ed. and trans. Mauammad 'Abdu'l Ghani, vol. III, text p. 311, trans. p. 340; Hutton, Bijapur, pp. 110-11; Katherine Butler Schofield, 'Learning to taste the emotions', pp. 407-10.

64. Nazir Ahmad, Ketab-e nauras, pp. 55-94; David J. Matthews, 'Eighty years of Dakani scholarship', pp. 92-94; Navina Najat Haidar, 'The Kitab-i nauras', p. 26.

65. Qazvini, Hālāt-e Asad Beg, fol. 170r.

66. Keelan Overton, 'Book culture', pp. 93-97, 113-17.

67. Hoseyn b. Gheyās al-Din Mahmud, Kheyr al-bayān, fols. 293v, 319v-322r; Devare, Persian Literature, pp. 67, 94-98, 186-236, 324-30; Browne, A Literary History of Persia, vol. IV, pp. 110, 253.

68. Tärikh-e Fereshta, vol. II, p. 153, and recall his important role in the construction of Nauraspur.

69. Keelan Overton, 'A Collector and his Portrait', pp. 44-115; See also Christopher D. Bahl, 'Histories of Circulation', pp. 128-35.

70. Tärikh-e Fereshta, vol. II, pp. 153-54. Rowzat al-safä' ('Garden of Purity') is a world history, written in the Timurid court of Herat by Mirkhvānd (d. 1498), completed by his grandson, Khvāndamir. This history was important in the development of Safavid historiographical traditions. See Maria Szuppe, 'Historiography, V: Timurid period'; Sholeh Quinn, Historical Writing, pp. 13-14, 39-40.

71. Tärikh-e Fereshta, vol. II, p. 156.

72. Golzār-i Ebrāhim, vol. III, text pp. 360-61, trans. pp. 368-70.

73. Verma, Social, Economic and Cultural History, p. 100.

74. Tārikh-e Fereshta, vol. II, pp. 171-74.

75. Deborah Hutton, 'Carved in stone', pp. 74-75, suggests that the monumental architecture from Ebrahim's reign reflects the continuation and codification of his predecessors' visual language rather than the rejection thereof.

76. See, for example, Sardar, 'Golconda through Time', pp. 21-65, 127-28, 132-33; Eaton and Wagoner, Power, Memory, Architecture, pp. 214-30; Vasumati, 'Ibrahim Qutb Shah and Telugu poets', pp. 28-42; idem, 'Telugu literature', pp. 54-65; Sherwani, Qutb Shahi, pp. 85-86, 525-40; Philip B. Wagoner, 'The multiple worlds of Amin Khan'.

77. Radhey Shyam argues that in Ahmadnagar, with the conversion of Borhan Nezam 
Shah, Shi'ism became the religion of the masses, a transition that was achieved peacefully, see Shyam, Ahmadnagar, p. 81. This, however, is far from likely; no evidence supports it other than a short reference in Fereshta, himself Shi' ${ }^{\circ}$. Other sources emphasize that Shi'ism remained a minority creed throughout the Deccan, marking the region as distinct from Iran. See, Nile Green, 'Shiism, Sufism and sacred space in the Deccan', pp. 195-97.

78. This issue is elaborated in my book, Local States in an Imperial World.

79. Nazir Ahmad's translation of the letter from Makāteb-e zamān-e salātin-e safaviya, Asafiya Library, Hyderabad, Ms. 1214, fol. 404ff., reprinted in Nayeem, External Relations, appendix I, pp. 275-76; facsimile in appendix VII.

80. Riyazul Islam, A Calendar of Documents on Indo-Persian Relations, vol. II, pp. 13135.

81. Nayeem, External Relations, pp. 52-62; Muzaffar Alam and Sanjay Subrahmanyam, The Mughal State, pp. 33-36.

82. Elizabeth Lambourn, 'Khutba and Muslim networks in the Indian Ocean (Part II)'.

83. Sebastian Prange, Monsoon Islam, pp. 263-67.

84. Dariusz Kołodziejczyk, 'What is inside and what is outside?', pp. 430-31.

85. Pushkar Sohoni,'The non-issue of coinage'. 


\section{Bibliography:}

Abisaab, Rula, Converting Persia: Religion and Power in the Safavid Empire (London: I.B. Tauris, 2004).

Ahmad, Nazir, ed. and trans., Ketāb-e nauras (New Delhi: Bharatiya Kala Kendra, 1956).

Alam, Muzaffar and Sanjay Subrahmanyam, eds, The Mughal State, 1526-1750

(New Delhi: Oxford University Press, 1998).

Allouche, Adel, The Origins and Development of the Ottoman-Safavid Conflict (906-962/1500-1555) (Berlin: Klaus Schwarz, 1983).

Arjomand, Said Amir, The Shadow of God and the Hidden Imam: Religion, Political Order, and Societal Change in Shi ite Iran from the Beginning to 1890 (Chicago: University of Chicago Press, 1984).

Atç1, Abdurrahman, Scholars and Sultans in the Early Modern Ottoman Empire (Cambridge: Cambridge University Press, 2017).

Babayan, Kathryn, Mystics, Monarchs, and Messiahs: Cultural Landscapes of Early Modern Iran (Cambridge, MA: Harvard University Press, 2002).

Bahl, Christopher D., 'Histories of Circulation: Sharing Arabic Manuscripts across the Western Indian Ocean, 1400-1700', doctoral dissertation (SOAS University of London, 2018).

Browne, E.G, A Literary History of Persia, vol. IV: A History of Persian Literature in Modern Times, A.D. 1500-1924 (Cambridge: Cambridge University Press, 1924).

Butler Schofield, Katherine, 'Learning to taste the emotions: The Mughal Rasika', in Tellings and Texts: Music, Literature and Performance in North India, ed. Francesca Orsini and Katherine Butler Schofield (Cambridge: Open Book Publishers, 2015), pp. 407-21.

— 'Music, art and power in 'Adil Shahi Bijapur, c. 1570-1630', in Scent upon a Southern Breeze: The Synaesthetic Arts of the Deccan, ed. Kavita Singh (Mumbai: Marg, 2018), pp. 68-87.

Casale, Giancarlo, 'The Islamic empires of the early modern world', in The Cambridge World History, VI: The Construction of a Global World, 14001800, Part 1: Foundations, ed. Jerry H. Bentley, Sanjay Subrahmanyam and Merry E. Wiesner-Hanks (Cambridge: Cambridge University Press, 2015), pp. 323-44.

Cole, Juan I.R., 'Iranian culture and South Asia, 1500-1900', in Iran and the Surrounding World: Interactions in Culture and Cultural Politics, ed. Nikki R. Keddie and Rudi Matthee (Seattle: University of Washington Press, 2002), pp. $15-35$.

Daftary, Farhad, The Ismā'ìliss: Their History and Doctrines (New York: Cambridge University Press, 2007).

Dale, Stephen F., The Muslim Empires of the Ottomans, Safavids, and Mughals (Cambridge: Cambridge University Press, 2009). 
Devare, T.N., A Short History of Persian Literature at the Bahmani, the Adilshahi, and the Qutbshahi Courts, Deccan ([Pune: S. Devare], 1961).

Devi, V. Yashoda, After the Kakatiyas (Hyderabad: Andhra Pradesh Sahitya Akademi, 1975).

Dickson, Martin M., 'Sháh Tahmásb and the Uzbeks (The Duel for Khurásán with 'Ubayd Khán: 930-946/1524-1540)', doctoral dissertation (Princeton: Princeton University, 1958).

Digby, Simon, 'Before Timur came: Provincialization of the Delhi Sultanate through the fourteenth century', Journal of the Economic and Social History of the Orient 47 (2004), pp. 298-356.

Dressler, Markus, 'Inventing orthodoxy: Competing claims for authority and legitimacy in the Ottoman-Safavid conflict', in Legimizing the Order: The Ottoman Rhetoric of State Power, ed. Hakan T. Karateke and Maurus Reinkowski (Leiden: Brill, 2005), pp. 151-73.

Eaton, Richard M., The Sufis of Bijapur, 1300-1700: Social Roles of Sufis in Medieval India (Princeton: Princeton University Press, 1978).

- A Social History of the Deccan, 1300-1761: Eight Indian Lives (Cambridge: Cambridge University Press, 2005).

Eaton, Richard M. and Phillip B. Wagoner, Power, Memory, Architecture: Contested Sites on India's Deccan Plateau, 1300-1600 (New Delhi: Oxford University Press, 2014).

- 'Warfare on the Deccan Plateau, 1450-1600: A military revolution in early modern India?', Journal of World History 25 (2014), pp. 5-50.

Ergene, Boğaç A., 'On Ottoman justice: Interpretations in conflict (1600-1800)', Islamic Law and Society 8 (2001), pp. 52-87.

Farooqi, Naimur Rahman, Mughal-Ottoman Relations (Delhi: Edāra-ye adabiyāt-e Delli, 1989).

Faroqhi, Suraiya, 'Seyyid Gazi revisited: The foundation as seen through sixteenth and seventeenth-century documents', Turcica 13 (1981), pp. 90122.

Fereshta, Mohammad Qāsem Hendu-Shāh Astarābādi, Tārikh-e Fereshta: Tārikh-e salätin-e hendustān, ed. John Briggs and Mir Khoirat Ali Khan, 2 vols (Bombay: Lithographed at the Government College Press, 1831).

Ferguson, Heather L., The Proper Order of Things: Language, Power, and Law in Ottoman Administrative Discourses (Stanford, CA: Stanford University Press, 2018).

Firouzeh, Peyvand, 'Sacred kingship in the garden of poetry: Ahmad Shāh Bahmani's tomb in Bidar (India)', South Asian Studies 31 (2015), pp. 187214.

Fischel, Roy S., Local States in an Imperial world: Identity, Society and Politics in the Early Modern Deccan (Edinburgh: Edinburgh University Press, 2020). 
Flatt, Emma J., 'The authorship and significance of the Nujum al-ulum: A sixteenth-century astrological encyclopedia from Bijapur', Journal of the American Oriental Society 131 (2011), pp. 223-44.

Fleischer, Cornell H., Bureaucrat and Intellectual in the Ottoman Empire: The Historian Mustafa Âli (1541-1600) (Princeton, NJ: Princeton University Press, 1986).

— 'The lawgiver as messiah: The making of the imperial image in the reign of Süleyman', in Soliman le Magnifique et son temps, ed. Gilles Veinstein (Paris: La Documentation Française, 1992), pp. 159-77.

Fukazawa, Hiroshi, The Medieval Deccan: Peasants, Social Systems and States, Sixteenth to Eighteenth Centuries (Delhi: Oxford University Press, 1991).

Green, Nile, 'Shiism, Sufism and sacred space in the Deccan: Counter-narratives of saintly identity in the cult of Shah Nur', in The Other Shiites: From the Mediterranean to Central Asia, ed. Alessandro Monsutti, Silvia Naef and Farian Sabahi (Bern: Peter Lang, 2007), pp. 195-218.

Guha, Sumit, 'Mārgī, Deśī, and Yāvanī: High language of ethnic speech in Maharashtra', in Mārga: Ways of Liberation, Empowerment, and Social Change in Maharashtra, ed. M. Naito, I. Shima and H. Kotani (New Delhi: Manohar, 2008), pp. 129-46.

- 'Serving the barbarian to preserve the dharma: The ideology and training of a clerical elite in Peninsular India c. 1300-1800', The Indian Economic and Social History Review 47 (2010), pp. 497-525.

Haidar, Navina Najat, 'The Kitāb-i nauras: Key to Bijapur's golden age', in Sultan of the South: Arts of India's Deccan Courts, 1323-1687, ed. Navina Najat Haidar and Marika Sardar (New Haven, CT; London: Metropolitan Museum of Art, 2011), pp. 26-43.

Herzig, Edmund and Willem Floor, 'Introduction', in Iran and the World in the Safavid Age, ed. Willem Floor and Edmund Herzig (London: I.B. Tauris, 2012), pp. 1-13.

Hoseyn b. Gheyās al-Din Mahmud, Kheyr al-bayān, British Museum, Persian Ms. Or. 3397.

Husain, Mahdi, Tughluq Dynasty (Calcutta: Thacker Spink \& Co., 1963).

Hutton, Deborah, 'Carved in stone: The codification of visual identity for the Indo-Islamic Sultanate of Bīdjāpūr', Archives of Asian Art 55 (2005), pp. 6578.

- Art of the Court of Bijapur (Bloomington: Indiana University Press, 2006).

Islam, Riyazul, A Calendar of Documents on Indo-Persian Relations, 15001750, 2 vols (Tehran: Iranian Culture Foundation and Karachi: Institute of Central and West Asian Studies, 1979-82).

Jackson, Peter, The Delhi Sultanate: A Political and Military History (Cambridge: Cambridge University Press, 1999).

Jones, Justin, Shi'a Islam in Colonial India: Religion, Community and Sectarianism (Cambridge: Cambridge University Press, 2012). 
Joshi, P.M., 'The 'Ādil Shāhis and the Baridis', in History of Medieval Deccan, 1295-1724, ed. H.K. Sherwani and P.M. Joshi (Hyderabad: Government of Andhra Pradesh, 1973-4), vol. II, pp. 289-394.

Kafadar, Cemal, Between Two Worlds: The Construction of the Ottoman State (Berkeley: University of California Press, 1995).

Khurshāh b. Qobād, al-Hoseyni, Tārikh-e Ilchi-ye Nezām-Shāh, ed. Mohammad Rezā Nasiri (Tehran: Anjoman-e āsār va mafākher-e farhangi, 1379/2000).

Kołodziejczyk, Dariusz, 'What is inside and what is outside? Tributary states in Ottoman politics', in The European Tributary States of the Ottoman Empire in the Sixteenth and Seventeenth Centuries, ed. Gabor Karman and Lovro Kuncevic (Leiden: Brill, 2013), pp. 421-32.

Lambourn, Elizabeth, 'Khutba and Muslim networks in the Indian Ocean (Part II), Timurid and Ottoman engagements', in The Growth of Non-Western Cities: Primary and Secondary Urban Networking, c. 900-1900, ed. Kenneth R. Hall (Lanham, MD: Lexington Books, 2011), pp. 127-54.

Matthews, David J., 'Dakani Language and Literature, 1500-1700 AD', doctoral dissertation (SOAS University of London, 1976).

'Eighty years of Dakani scholarship', Annual of Urdu Studies 8 (1993), pp. 82-99.

Michell, George and Mark Zebrowski, Architecture and Art of the Deccan Sultanates (Cambridge: Cambridge University Press, 1999).

Mill, James, The History of British India (London[?]: [n.p.], 1817).

Mitchell, Colin P., The Practice of Politics in Safavid Iran: Power, Religion and Rhetoric (London: I.B. Tauris, 2009).

Momen, Moojan, An Introduction to Shi' i Islam: The History and Doctrines of Twelver Shi ism (New Haven: Yale University Press, 1985).

Nayeem, M.A., External Relations of the Bijapur Kingdom (1489-1686 A.D.) (Hyderabad: Bright Publishers, 1974).

Nazim, M., Bijapur Inscriptions: Memoirs of the Archceological Survey of India 49 (Delhi: Manager of Publications, 1936).

Overton, Keelan, 'A Collector and his Portrait: Book Arts and Painting for Ibrahim 'Adil Shah II of Bijapur (r. 1580-1627)', doctoral dissertation (University of California-Los Angeles, 2011).

- 'Book culture, royal libraries, and Persianate painting in Bijapur, circa 1580 1630', Muqarnas 33 (2016), pp. 91-154.

Prange, Sebastian R., Monsoon Islam: Trade and Faith on the Medieval Malabar Coast (Cambridge: Cambridge University Press, 2018).

Qazvini, Asad Beg, Ketāb-i hālāt-e Asad Beg Qazvini, British Library, Ms. Or 1837.

Quinn, Sholeh A., Historical Writing during the Reign of Shah 'Abbas: Ideology, Imitation and Legitimacy in Safavid Chronicles (Salt Lake City: University of Utah Press, 2000). 
Sardar, Marika, 'Golconda through Time: A Mirror of the Evolving Deccan', doctoral dissertation (New York University, 2007).

Sarkar, Jagadish Narayan, The Life of Mir Jumla, the General of Aurangzeb (Calcutta: Thacker, Spink \& Co., 1951).

Savory, Roger M., Iran under the Safavids (Cambridge: Cambridge University Press, 1980).

Sharma, S.R., 'A note on the cultural background of political struggles in Medieval Deccan', Proceedings of the Deccan History Conference, Hyderabad, First Session (1945), pp. 171-77.

Sherwani, H.K., 'The "independence” of Bahmani governors', Proceedings of the Indian History Congress, Seventh Session, Madras (1944), pp. 256-62.

- The Bahmanis of the Deccan (Hyderabad: Saood Manzil, 1953).

- History of the Qutb Shahi Dynasty (New Delhi: Munshiram Manoharlal, 1974).

Shirāzi, Nezām al-Din Ahmad, Hadīqat al-salātin, ed. 'Ali Asghar Bilgrami (Hyderabad: Islamic Publications Society, 1961).

Shirāzi, Rafi‘ al-Din Ebrāhim, Tadhkerat al-moluk, Telangana (formerly Andhra Pradesh) Oriental Manuscript Library, Hyderabad, Persian Ms. history 1081.

Shyam, Radhey, The Kingdom of Ahmadnagar (Delhi: Motilal Banarsidass, 1966).

Siddiqi, Muhammad Suleman, The Bahmani Șūfis (Delhi: Edāra-ye adabiyāt-e Delli, 1989).

— 'The ethnic change at Bidar and its influence (AD 1422-1538)', in Medieval Deccan History: Commemoration Volume in Honour of Purshottam Mahadeo Joshi, ed. A.R. Kulkarni, M.A. Nayeem and T.R. de Souza (Bombay: Popular Prakashan, 1996), pp. 33-51.

Sinha, S.K., Medieval History of the Deccan, Vol. 1: Bahmanids (Hyderabad: Government of Andhra Pradesh, 1964).

Sohoni, Pushkar, 'The non-issue of coinage: The monetary policies of the postBahmani sultanates', Journal of the Royal Asiatic Society, third series 28 (2018), pp. 645-59.

Subrahmanyam, Sanjay, 'Iranians abroad: Intra-Asian elite migration and early modern state formation', Journal of Asian Studies 51 (1992), pp. 340-63.

- 'Of imarat and tijarat: Asian merchants and state power in the western Indian Ocean, 1400 to 1750', Comparative Studies in Society and History 37 (1995), pp. 750-80.

Szuppe, Maria, 'Historiography v. Timurid period', Encyclopaedia Iranica, vol. XII, fasc. 4 (2003), pp. 356-63.

Tabasi, Qāsem, Enshā-ye Qāsem Ṭabasi, British Library, Ms. IO Persian 18. 
Vasumati, E., 'Ibrahim Qutb Shah and Telugu poets', in Qutb Shahi Sultans and Andhra Samskriti, ed. S.M. Qadri Zore (Hyderabad: Idāra-e-Adabiyāt-eUrdu, 1962), pp. 28-42.

- Telugu Literature in the Qutub Shahi Period (Hyderabad: Abul Kalam Azad Oriental Research Institute, 196?).

Verma, D.C., Social, Economic and Cultural History of Bijapur (Delhi: Edāraye adabiyāt-i Delli, 1990).

Wagoner, Phillip B., "Sultan among Hindu kings": Dress, titles, and Islamicization of Hindu culture at Vijayanagara', Journal of Asian Studies 55 (1996), pp. 851-80.

- 'The multiple worlds of Amin Khan: Crossing Persianate and Indic cultural boundaries in the Qutb Shahi Kingdom', in Sultans of the South: Arts of India's Deccan courts, 1323-1687, ed. Navina Najat Haidar and Marika Sardar (New Haven, CT and London: Metropolitan Museum of Art, 2011), pp. 90-101.

Yazdani, G. 'Inscriptions of Shahpur, Gogi and Sagar-Gulbarga District', Epigraphia Indo-Moslemica (1931-32), pp. 1-24.

- Bidar: Its History and Monuments (London: Oxford University Press, 1947).

Yllmaz, Hüseyin, Caliphate Redefined: The Mystical Turn in Ottoman Political Thought (Princeton and Oxford: Princeton University Press, 2018).

Zohuri, Golzār-e Ebrāhìm, in A History of Persian Language and Literature at the Mughal Court, ed. and trans. Mauammad 'Abdu'l Ghani (Allahabad: The Indian Press, 1930), vol. III, text pp. 347-62, translation pp. 365-422.

- Nauras, in A History of Persian Language and Literature at the Mughal Court, ed. and trans. Mauammad 'Abdu'l Ghani (Allahabad: The Indian Press, 1930), vol. III, text pp. 307-20, translation pp. 323-45. 

